\title{
Kinerja Pengrajin Boneka di Kota Bekasi, Jawa Barat dalam Penerapan Standar Nasional Indonesia Mainan Anak
}

\section{Performance of Doll Craftsman in Bekasi, West Java in Indonesian National Standard of Children Toys Implementation}

\author{
Tintin Prihatiningrum ${ }^{1}$, Pudji Muljono ${ }^{2}$, Dwi Sadono ${ }^{2}$ \\ ${ }^{1}$ Badan Standardisasi Nasional, Jakarta \\ ${ }^{2}$ Departemen Sains Komunikasi dan Pengembangan Masyarakat, Fakultas Ekologi Manusia, \\ Institut Pertanian Bogor, Bogor
}

\begin{abstract}
Government of Indonesia has issued a regulation regarding The Mandatory of Indonesian National Standard (SNI) on Children Toys, but most of the doll craftsman as a small scale industry not ready yet. The objectives of this study were: 1) to analyze the performance of doll craftsman in Bekasi in the implementation of SNI ofchildren toys, 2) to analyze the factors related to the performance of doll craftsman in Bekasi in the implementation of SNI of children toys. This research was conducted in April to December 2015 in Bekasi. The population were 46 core doll craftsman. Thedata collection was conducted by census on the population. The analysis of data was performed by using the correlation test of rank Spearman. The results of this research show that the performance level of the doll craftsman in Indonesian National Standard of Children Toys Implementation is high. The characteristic factors correlated with performance were formal education, business experience, the ability to meet market demand and business investment. The motivation factors correlated with performance is needs for power. The external factors correlated with performanceare the availability of information and the level of doll craftsman empowerment through training. None of theattribute of innovation factors correlated with performance.
\end{abstract}

Key words: Indonesian national standard, implementation of SNI, performance, doll craftsman

Abstrak

Pemerintah Indonesia telah mengeluarkan peraturan tentang pemberlakuan wajib Standar Nasional Indonesia (SNI) pada mainan anak, tetapi sebagian besar pengrajin boneka yang merupakan Usaha Kecil Menengah (UKM) belum siap. Tujuan penelitian ini adalah: 1) menganalisis kinerja boneka pengrajin di Kota Bekasi dalam penerapan SNI mainan anak, 2) menganalisis faktorfaktor yang berhubungan dengan kinerja pengrajin boneka di Kota Bekasi dalam penerapan SNI mainan anak. Penelitian dilakukan pada bulan April sampai dengan Desember 2015 di Kota Bekasi. Populasi penelitian ini adalah 46 pengrajin inti. Pengumpulan data dilakukan dengan cara sensus terhadap seluruh populasi. Data yang diperoleh dianalisis menggunakan uji korelasirank Spearman. Hasil penelitian ini menunjukkan bahwa tingkat kinerja pengrajin boneka dalam penerapan SNI mainan anak tergolong kategori tinggi. Hasil analisis korelasi rank Spearman menunjukkan bahwa faktor karakteristik yang berkorelasi dengan kinerja adalah pendidikan formal, pengalaman bisnis, kemampuan memenuhi permintaan pasar dan investasi usaha. Hasil analisis juga menunjukkan bahwa faktor motivasi yang berkorelasi dengan kinerja adalah kebutuhan kekuasaan. Sedangkan faktor eksternal yang berkorelasi dengan kinerja adalah tingkat ketersediaan informasi dan pemberdayaan pengrajin melalui pelatihan. Tidak satu pun dari faktor atribut inovasi yang berkorelasi dengan kinerja.

Kata kunci: Standar Nasional Indonesia, penerapan SNI, kinerja, pengrajin boneka

\section{Pendahuluan}

Pengrajin boneka di Indonesia dalam beberapa kurun waktu terakhir ini telah berpusat di Kota Bekasi, setelah sebelumnya, selamanya dua dekade sempat berkembang di daerah Bandung dan Cengkareng. Awal mula hadirnya pengrajin boneka di Kota Bekasi ditandai dengan krisis moneter yang terjadi pada tahun 1998 dan membuat beberapa pabrik boneka asing di Kota Bekasi yang menutup pabriknya sehingga terjadi pemutusan hubungan kerja. Kebutuhan ekonomi dan lapangan kerja membuat beberapa orang kemudian membangun usaha pembuatan boneka yang terus berkembang hingga saat ini.

Indonesia sebagai negara dengan populasi anak usia di bawah 14 tahun yang berdasarkan $C I A$ World Factbook mencapai lebih dari 25\%. Mainan anakadalah salah satu sasaran utama industri global, menurut Kementerian Perdagangan, hingga bulan Agustus 2013 nilai impor mainan anak telah mencapai

${ }^{1}$ Korespondensi penulis E-mail: tintinbsn@gmail.com 
60 juta dolar, dengan 95\% diantaranya berasal dari Cina. Namun, belum tentu seluruh mainan yang beredar itu aman untuk anak, hingga kemudian standar mainan anak diberlakukan wajib (Suryowati, 2013).

Pemberlakuan wajib standar mainan anak untuk produksi boneka di Indonesia, yang juga mengatur berbagai jenis mainan lainnya seperti kelereng, puzzle, baby walker dan lainnya. Standar merupakan sebuah inovasi yang penting bagi industri karena memberikan dampak perbaikan pada setiap produk, baik berupa barang maupun layanan jasa, mulai dari alat transportasi, alat komunikasi, barang-barang elektronik hingga kebutuhan sandang pangan seharihari. Standar awalnya diterbitkan untuk memastikan barang dan jasa agar dapat diproduksi dan digunakan pada negara yang berbeda. Standar juga digunakan untuk mengurangi hambatan perdagangan barang dan jasa sehingga dapat diperdagangkan dengan bebas di seluruh dunia. Standar berlaku secara nasional maupun internasional dan pada dasarnya penerapannya bersifat sukarela (BSN, 2011).

Bagi pengrajin boneka, peluang dalam menghadapi tantangan tersebut adalah dengan meningkatkan kemampuan dan mencapai kinerja maksimal dalam menghasilkan produk-produk boneka yang berkualitas dan aman. Kinerja tersebut salah satunya terkait pada peningkatan jumlah produksi boneka sesuai dengan permintaan pasar dan pemenuhan standar yang menjamin kekuatan fisik boneka serta keamanan zat kimia yang terkandung dalam bahan-bahan pembuatnya. Pemenuhan standar ini, selain karena SNI mainan anak sudah wajib, juga untuk menghindari konsekuensi yang tidak diinginkan.

SNI adalah satu-satunya standar yang berlaku nasional di seluruh Indonesia, dirumuskan panitia teknis yang berada di masing-masing institusi teknis terkait dan ditetapkan Badan Standardisasi Nasional (BSN) sebagai lembaga pemerintah yang bertugas dalam pengembangan kegiatan standardisasi di Indonesia. Terhitung sejak Oktober 2013 lalu, di Indonesia, melalui Peraturan Menteri Perindustrian No.24/M-Ind/ PER/4/2013 dengan revisi melalui Peraturan Menteri No.55/M-IND/PER/11/2013 tentang pemberlakuan SNI mainan anak secara wajib. SNI ini secara umum mengatur di antaranya spesifikasi sifat fisis dan mekanis (SNI ISO 8124-1:2010), spesifikasi sifat mudah terbakar (SNI ISO 8124-2:2010), perpindahan unsur tertentu atau migrasi zat kimia (SNI ISO 8124-3:2010), persyaratan zat warna azo dan kadar formaldehida (SNI 7617:2010) (Kemenperin, 2013).

Pemberlakukan SNI Wajib mainan anak di Indonesiamenentukan persyaratan bahwa mainan harus dibuat cukup besar (diameter 1,75 inci atau 4,4 sentimeter) dengan bagian yang tidak mudah lepas agar tidak berisiko tertelan, terutama untuk anak di bawah tiga tahun. Mainan yang beredar harus dibuat dari material atau bahan yang tidak mudah terbakar, memiliki permukaan dan sudut yang halus, dibuat kuat, kokoh dan tidak mudah pecah sehingga tidak menggores dan melukai anak. Mainan lipat atau mainan berengsel harus dirancang dengan aman agar tidak menjepit jari anak. Pemakaian zat kimia yang berbahaya tidak diperkenankan karena berpotensi terjadinya keracunan ataupun kematian.

Parameter persyaratan kritikal sesuai Annex B SNI ISO 8124-1:2010 menyebutkan bahwa terdapat poin-poin pentingnya label keselamatan peringatan bahaya tersedak atau kemungkinan bahaya lain yang dapat ditimbulkan oleh mainan, penandaan pabrik berisi nama dan alamat produsen atau produsen dalam bahasa Indonesia.

Pengujian fisis dan mekanis diantaranya meliputi uji bagian kecil, aksesibilitas, uji ujung dan sisi tajam, runcing, tali, beban, kinetik, uji jatuh artinya mainan tidak pecah saat dijatuhkan berkali-kali dari ketinggian tertentu. Uji puntir 180 derajat atau 0,45 Nm selama 10 detik untuk memastikan mainan tidak mudah patah atau terlepas, uji tekan dengan gaya 114 sampai dengan $138 \mathrm{~N}$ selama 10 detik memastikan mainan tidak mudah pecah. Uji Tarik $70 \mathrm{~N}$ digunakan untuk memastikan jahitan atau bagian mainan tidak mudah terlepas, pukul, dan suara.

Sementara pengujian sifat mudah terbakar sesuai SNI ISO 8124-2:2010 akan memastikan mainan dengan bahan-bahan yang mudah terbakar, seperti tekstil, bahan tenda atau terpal, telah dikondisikan dalam suhu tertentu dapat bertahan dari rata-rata tingkat keterbakaran. Uji bakar harus dilakukan pada mainan berbulu seperti boneka untuk memastikan mainan tidak mengandung seluloid atau mengandung cairan yang mudah terbakar dengan laju bakar kurang dari $30 \mathrm{~mm}$ per detik.

Penguji kimia sesuai SNI ISO 8124-3:2010 dilakukan untuk mengetahui kandungan zat kimia sesuai batas maksimal zat berbahaya seperti antimoni (Sb) tidak boleh lebih dari 60 ppm, arsenic (As) tidak boleh lebih dari 25 ppm, barium (Ba) tidak boleh lebih dari 1000 ppm, kadmium (Cd) tidak boleh lebih dari 75 ppm, Kromium (Cr) tidak boleh lebih dari 60 ppm, timbal $(\mathrm{Pb})$ tidak boleh lebih dari 90 ppm, merkuri (Hg) tidak boleh lebih dari 60 ppm, dan selenium (Se) tidak boleh lebih dari 500 ppm. 
Pada mainan dengan bahan dasar kain harus diuji persyaratan zat warna azo dan formaldehida sesuai SNI 7617:2010. Zat warna azo tidak boleh lebih dari 20 ppm karena bersifat beracun, mutagenik, karsiogenik dan alergi, pewarna ini biasa digunakan untuk memberi warna cerah dan bersifat tidak biodegradabel serta sulit hilang dari ekosistem. Formaldehida digunakan pada tekstil sebagai pengikat pigmen azo agar warna tahan lama, zat ini tidak boleh lebih dari 75 ppm karena bersifat berbahaya bila tertelan dapat menimbulkan muntah-muntah dan iritasi saluran pernapasan, untuk jangka panjang dapat menyebabkan kanker, mengacaukan susunan DNA. Parameter keselamatan lainnya adalah persyaratan kandungan phthalates atau ftalat sesuai EN 71-5, zat ini adalah senyawa kimia yang ditambahkan ke plastik agar lebih lentur. Zat ini sedikit demi sedikit akan terlepas dan berbahaya jika sampai tertelan karena bertindak sebagai anti androgen. Phthalates dengan jenis DBP, BBP, DEHP, DINP, DNOP dan DIDP tidak boleh lebih dari 0,1 persen.

Seluruh ketentuan dalam peraturan tersebut berlaku untuk mainan anak di bawah usia 14 tahun, baik saat awal diterima konsumen, penggunaan normal hingga penggunaan kasar. Hal ini bertujuan untuk mengurangi risiko dan bahaya penggunaan mainan anak. Persyaratan administrasi, persyaratan sertifikasi dan persyaratan penandaan harus dipenuhi oleh seluruh industri mainan anak, baik untuk skala usaha kecil, sedang, maupun besar, buatan dalam maupun luar negeri. Jika tidak maka produk mainan anak yang diproduksi tidak boleh beredar di Indonesia.

Ketentuan ini memberi dampak yang luas dari sisi kelangsungan usaha kecil menengah, ketenagakerjaan serta devisa negara. Bagi pengrajin, tantangan ini dapat menjadi sebuah nilai tambah, namun juga dapat menjadi hambatan bagi kelangsungan usaha. Peraturan ini masih baru dan belum banyak dilakukan penelitian terkait hal tersebut, karena itu penelitian ini menjadi penting untuk dilakukan. Berdasarkan kondisi tersebuttujuan dalam penelitian ini dirumuskan sebagai berikut: 1) menganalisis kinerja pengrajin boneka di Kota Bekasi dalam penerapan SNI mainan anak, 2) menganalisis faktor-faktor yang berhubungan dengan kinerja pengrajin boneka di Kota Bekasi dalam penerapan SNI mainan anak.

\section{Metode Penelitian}

Penelitian ini menggunakan pendekatan kuantitatif, metode penelitian yang dipilih untuk menjawab pertanyaan dan tujuan penelitian digunakan metode survei. Ciri metode ini adalah data dikumpulkan dari responden dengan menggunakan kuesioner dan merupakan upaya dalam mengungkapkan suatu fenomena sosial yang menarik perhatian peneliti (Effendi, 2012). Prosedur statistik yang digunakan untuk menguji adalah Analisis Statistika Deskriptif, melalui ini akan diberikan gambaran mengenai berbagai aspek yang berhubungan dengan variabel kinerja pengrajin boneka dalam penerapan SNI mainan anak, dari nilai responden yang dibagi ke dalam tiga kelas kriteria sesuai interval yang telah ditentukan. Sedangkan analisis korelasional digunakan untuk mengukur kekuatan hubungan antar variabel. Melalui analisis korelasional dilakukan uji statistik non parametrik, yaitu korelasi rank Spearman,untuk melihat hubungan antara variabel $\mathrm{X}$ dan $\mathrm{Y}$ yang telah ditetapkan.

Penelitian dilakukan di Kota Bekasi, yang memiliki 12 kecamatan dan 56 kelurahan. Penentuan lokasi dilakukan secara sengaja dengan pertimbangan Kota Bekasi merupakan sentra pengrajin boneka di Indonesia yang pengrajinnya mendapat pendampingan penerapan SNI dari pemerintah. Penelitian dilaksanakan mulai dari bulan April sampai dengan Desember 2015. Populasi dalam penelitian ini adalah pengrajin boneka di Kota Bekasi, yang menurut data Dinas Perindag Kota Bekasi berjumlah 46 orang pengrajin inti. Pengumpulan data dan informasi dilakukan dengan cara sensus pada seluruh pengrajin inti.Seluruh pengrajin inti diwawancara satu per satu dengan menggunakan kuesioner sebagai panduan wawancara. Data primer yang dikumpulkanmelalui kuesioner tersebut adalah data karakteristik pengrajin, motivasi wirausaha, faktor eksternal pengrajin boneka dan atribut inovasi SNI mainan anak, sedangkan variabel terikat adalah Kinerja Pengrajin. Dalam mengumpulkan data primer, peneliti menggunakan kuesioner yang bertujuan untuk memperoleh informasi yang relevan dengan tujuan penelitian, dan memperoleh informasi yang memiliki validitas dan reliabilitas tinggi.

Data sekunder didapatkan melalui berbagai literatur, baik dari lembaga terkait maupun buku dan penelitian sebelumnya. Data tersebut berupa dokumen SNI, dokumen peraturan yang berlaku, profil daerah Kota Bekasi, serta materi-materi sosialisasi penerapan SNI mainan anak. Informan pada penelitian ini adalah pegawai dan penyuluh Dinas Perindag Bekasi yang menangani pembinaan dan pendampingan terhadap pengrajin boneka di Bekasi, pegawai Kementerian 
Perindustrian RI yang menangani IKM Wilayah II. Analisis data menggunakan uji korelasi rank Spearman, dengan menggunakan SPSS 22.

\section{Hasil dan Pembahasan}

\section{Karakteristik Pengrajin Boneka di Kota Bekasi}

Karakteristik pengrajin yaitu identitas individu pengrajin yang diamati dalam penelitian yang diduga berhubungan dengan kinerja pengrajin boneka dalam penerapan SNI mainan anak. Karakteristik pengrajin jika dilihat dari latar belakang pendidikan formal termasuk beragam, mulai dari sekolah dasar hingga sarjana, sebesar 73,9\% menjalani pendidikan sekolah menengah pertama dan sekolah menengah atas, sementara 10,9\% lainnya menjalani pendidikan tinggi. Kondisi perekonomian yang baik dan lokasi tempat tinggal pengrajin yang sangat dekatdengan Ibukota Jakarta membuat mereka memiliki akses pendidikan yang mudah dan motivasi yang tinggi untuk menjalani pendidikan formal. Pengrajin di Kota Bekasi menjadi memiliki sikap yang terbuka pada berbagai upaya meningkatkan keterampilan dan pengetahuan yang baru.

Pengrajin boneka di Kota Bekasi mayoritas menjalankan usaha ini kurang dari 7,7 tahun. Pengrajin yang paling lama menjalankan usaha ini adalah 20 tahun dan ada juga pengrajin yang belum 2 tahun dalam menjalankan usaha ini. Sebagian pengrajin boneka tersebut bersama-sama mendirikan asosiasi untuk berbagi ilmu dan melindungi anggotanya, di antaranya dari kelangkaan serta tingginya harga bahan baku.

Kapasitas produksi masing-masing pengrajin sangat beragam, dimulai dari yang terkecil sekitar 200 buah, hingga yang mampu memenuhi sekitar 40.000 buah setiap bulannya. Sebagian besar permintaan datang dari Pulau Jawa, sebagian lagi datang dari luar Jawa di berbagai kota besar di Indonesia, sementara hingga saat ini di antara pengrajin yang menjadi responden dalam penelitian ini belum ada yang mengirim produknya ke luar negeri. Secara keseluruhan jika dirata-rata kemampuan para pengrajin boneka di Kota Bekasi dalam memenuhi permintaan pasar cukup tinggi, 73\% sampai dengan 100\% setiap bulannya.

Pengrajin di Kota Bekasi didominasi oleh industri dengan jumlah tenaga kerja 20 sampai dengan 99 orang, berdasarkan klasifikasi industri menurut
BPS berarti termasuk industri sedang atau menengah, selain itu terdapat juga beberapa industri rumah tangga dan industri kecil. Para pengrajin tersebut menjalankan mesin produksi yaitu mesin jahit dan mesin potong sebanyak 2 sampai dengan 18 buah.

Upaya pemenuhan semua permintaan pasar, pengrajin di Kota Bekasi rata-rata menanamkan modal usaha sebesar 50 sampai dengan 500 juta rupiah, atau sesuai dengan Undang-Undang No. 20 Tahun 2008 tentang Usaha Mikro, Kecil dan Menengah termasuk kriteria usaha kecil yaitu organisasi yang menghasilkan barang/jasa dan memiliki kekayaan bersih lebih dari 50 juta rupiah sampai dengan paling banyak 500 juta rupiah, tidak termasuk tanah dan bangunan tempat usaha.

Salah satu usaha untuk mengatasi modal usaha dan pemasaran beberapa pengrajin mendirikan koperasi, yang juga digunakan untuk mendapatkan sertifikasi SNI. Pengrajin di Kota Bekasi sedang dalam taraf perkembangan yang positif, mereka mau meningkatkan daya kreatifitasnya, sehingga produk yang dihasilkan tidak monoton.

\section{Motivasi Wirausaha Pengrajin}

Motivasi pada dasarnya adalah dorongan dari dalam diri seseorang yang dapat dipengaruhi oleh berbagai hal di luar dirinya. Berdasarkan McClelland (1961) dalam berwirausaha, seseorang dipengaruhi berbagai motivasi sesuai teorinya yaitu teori tiga motif sosial, motivasi pada saat seseorang melakukan kegiatan kewirausahaan tersebutadalah kebutuhan akan prestasi (need for achievement) dorongan keinginan mendapatkan prestasi dan pengakuan dari orang lain, kebutuhan kekuasaan (need for power) yaitu dorongan keinginan mendapatkan kekuasaan atas sumberdaya yang ada, dan kebutuhan afiliasi (need for affiliation) yaitu dorongan keinginan untuk berhubungan dengan orang lain secara sosial kemasyarakatan.

Pengrajin boneka di Kota Bekasi memiliki motivasi wirausaha berdasarkan tingkat kebutuhan prestasi yang tergolong sedang (Tabel 1). Motivasi ini dilihat dari keinginan meningkatkan keadaan ekonomi, menghasilkan produk yang bermutu untuk masyarakat dan keinginan meningkatkan status sosial.

Berdasarkan kebutuhan kekuasaan pengrajin tergolong kategori sedang, motivasi ini dilihat dari keinginan untuk berpengaruh terhadap lingkungannya, dengan cara mempertahankan usahanya dan 
Tabel 1. Rentang Skor Motivasi Wirausaha Pengrajin Boneka di Kota Bekasi dalam Penerapan SNI Mainan Anak

\begin{tabular}{lclcrc}
\hline No & Motivasi wirausaha pengrajin $\left(\mathbf{X}_{\mathbf{2}}\right)$ & Kategori & Rentang skor & Jumlah & $\%$ \\
\hline \multirow{2}{*}{1} & \multirow{2}{*}{ Tingkat kebutuhan akan prestasi } & rendah & $7,0-8,7$ & 8 & 17,4 \\
& & sedang & $8,8-10,3$ & 25 & 54,3 \\
& \multirow{2}{*}{ Tingkat kebutuhan kekuasaan } & tinggi & $10,4-2,0$ & 13 & 28,3 \\
& rendah & $6,0-7,7$ & 9 & 19,6 \\
& sedang & $7,8-9,3$ & 31 & 67,4 \\
\multirow{2}{*}{3} & Tingkat kebutuhan afiliasi & tinggi & $9,4-11,0$ & 6 & 13,0 \\
& & rendah & $7,0-8,7$ & 11 & 23,9 \\
& sedang & $8,8-10,3$ & 21 & 45,7 \\
\hline
\end{tabular}

Keterangan: $\mathrm{n}=46$

menyediakan lapangan kerja bagi para pekerja dan para pengrajin plasma, sehingga dapat memiliki kedudukan khusus di masyarakat sebagai seseorang yang memberikan manfaat bagi masyarakat.

Motivasi wirausaha berdasarkan kebutuhan afiliasi juga tergolong kategori sedang, motivasi ini dilihat dari keinginan berwirausaha karena ingin bekerjasama dengan orang lain, keinginan memperluas pergaulan dan kebutuhan akan sebuah komunitas. Para pengrajin boneka di Kota Bekasi sebagian besar tergabung dalam sebuah komunitas, dalam komunitas tersebut mereka bekerjasama menghadapi tantangan terkait bahan baku, pemasaran dan permodalan.

\section{Faktor Eksternal Pengrajin}

Tabel 2. Rentang Skor Faktor Eksternal Pengrajin
Rogers (2003) menyebutkan media massa dalam teori hypodermic needle model atau teori jarum suntik dianggap memiliki pengaruh langsung, segera dan kuat pada pemirsanya. Sementara dalam two-step flow model media massa dianggap sebagai pembentuk pengetahuan dan komunikasi interpersonal seperti yang dilakukan instansi pemerintah, tenaga penyuluh lapangan, pengrajin lain dan lembaga sertifikasi produk dianggap lebih penting dalam mempengaruhi proses adopsi.

Tingkat ketersediaan informasi mengenai penerapan SNI mainan anak tergolong sedang, (Tabel 2). Informasi ini didapatkan dari media massa, instansi pemerintah, tenaga penyuluh lapangan dan pengrajin lain, serta lembaga sertifikasi produk. Hal ini disebabkan kurangnya frekuensi pertemuan dengan

\begin{tabular}{cclccc}
\hline No & Faktor eksternal pengrajin $\left.\mathbf{(}_{\mathbf{3}}\right)$ & Kategori & Rentang skor & Jumlah & \% \\
\hline \multirow{2}{*}{1} & \multirow{2}{*}{ Tingkat ketersediaan informasi } & rendah & $9,0-12,0$ & 11 & 23,9 \\
& & sedang & $12,1-15,0$ & 18 & 39,1 \\
& & tinggi & $15,0-18,0$ & 17 & 37,0 \\
\multirow{2}{*}{2} & \multirow{2}{*}{ Tingkat insentif } & rendah & $6,0-9,7$ & 7 & 15,2 \\
& & sedang & $9,8-13,3$ & 24 & 52,2 \\
& & tinggi & $13,4-17,0$ & 15 & 32,6 \\
\multirow{2}{*}{3} & Tingkat pendampingan & rendah & $6,0-9,7$ & 7 & 15,2 \\
& & sedang & $9,8-13,3$ & 19 & 41,3 \\
& & tinggi & $13,4-17,0$ & 20 & 43,5 \\
\multirow{2}{*}{4} & Tingkat pemberdayaan & rendah & $5,0-8,7$ & 13 & 28,3 \\
& & sedang & $8,8-12,3$ & 30 & 65,2 \\
\hline
\end{tabular}


penyuluh karena terbatasnya jumlah tenaga penyuluh lapangan dan setiap penyuluh menangani berbagai jenis industri. Saat ini di Dinas Perindag Kota Bekasi terdapat 3 tenaga penyuluh lapangan dan 1 tenaga magang penyuluh IKM. Informasi yang dirasakan paling bermanfaat adalah prosedur penerapan SNI dan persyaratan untuk memperoleh tanda SNI termasuk informasi mengenai peraturan pemerintah yang terkait penerapan SNI. Pengrajin juga merasa informasi tentang peningkatan kualitas produk, manfaat penerapan SNI dan persaingan pasar bermanfaat bagi mereka.

Insentif menurut Rogers (2003) adalah suatu hal yang diberikan baik berupa uang maupun bentuk lainnya yang ditujukan untuk mendorong adanya perubahan perilaku dengan meningkatkan keuntungan relatif dari sebuah ide atau inovasi baru. Salah satu insentif yang diberikan adalah publikasi, sesuai Peraturan Direktur Jenderal Basis Industri Manufaktur (BIM) Nomor. 02/BIM/PER/1/2014 tentang Petunjuk Teknis Pelaksanaan Pemberlakuan dan Pengawasan SNI Mainan Secara Wajib dilaksanakan melalui pemberian penghargaan, pemuatan berita dalam media cetak dan elektronik yang bertujuan untuk sosialisasi, memberikan informasi, dan pemahaman terhadap masyarakat atas penerapan SNI secara wajib. Publikasi ini dilakukan salah satunya untuk menghargai ketaatan penerapan SNI oleh produsen dan pelaku usaha lainnya serta pihak terkait (Kemenperind, 2014).

Tingkat insentif penerapan SNI mainan anak berupa biaya sertifikasi, pelatihan pemahaman dokumen SNI, pendampingan pengujian produk dan publikasi di media massa tergolong kategori sedang. Sedangkan tingkat pendampingan penerapan SNI mainan anak tergolong tinggi. Pendampingan yang didapatkan berupa konsultasi, pelatihan, penyuluhan, dan bimbingan teknik cara menerapkan SNI dan birokrasi pengajuan SPPT SNI, serta pengujian produk.Insentif yang diberikan kepada pengrajin salah satunya melalu koperasi bersama untuk meringankan biaya sertifikasi dan mengatasi tingginya harga bahan baku, pemberian insentif ini tidak lepas dari proses pendampingan yang diberikan oleh pemerintah sebagai proses edukasi dan perubahan perilaku, hal ini sesuai dengan hasil penelitian Ocktilia (2004) yang menyebutkan bahwauntuk mencapai keberhasilan sebuah program pemberdayaan ekonomi rakyat diperlukan adanyaidentifikasi terhadap potensi lokal dan optimalisasi peranan koperasi melalui kemitraan dalam bidang permodalan, pengadaan bahan baku, pemasaran dan penyelenggaraan pendidikan dan latihan.

Tingkat pemberdayaan melalui pelatihan tergolong kategori sedang.Pemberdayaan adalah proses di mana pengrajin didukung agar mampu meningkatkan kesejahteraan. Pemberdayaan seperti disebutkan dalam Mardikanto (2015) bertujuan memperbaiki pendidikan dan aksesibilitas yang mampu menumbuhkan semangat belajar seumur hidup dan diharapkan akan memperbaiki bisnis yang dilakukan dan memperbaiki kehidupan masyarakat yang tercermin dalam perbaikan pendapatan. Pemberdayaan pada pengrajin boneka di Kota Bekasi dilakukan melalui penyelenggaraan pelatihan manajemen usaha, keterampilan pembuatan boneka dan pemahaman dokumen SNI diselenggarakan oleh Dinas Perindag Kota Bekasi, sebagian besar pengrajin merasa pelatihan ini sangat bermanfaat untuk meningkatkan usaha, meningkatkan keterampilan, menambah wawasan dan pengalaman dalam pengetahuan manajemen usaha, meningkatkan mutu produk.

\section{Atribut Inovasi SNI Mainan Anak}

Suatu inovasi atau sistem baru, biasanya akan melalui berbagai proses sebelum akhirnya diterima oleh masyarakat. Sebuah inovasi memerlukan waktu untuk kemudian diadopsi oleh individu ataupun sekelompok masyarakat. Menurut Rogers (2003), adopsi adalah keputusan untuk memanfaatkan sepenuhnya dari suatu inovasi sebagai tindakan yang terbaik dan melewati urutan tahapan sebelum penerimaan produk baru, sedangkan penolakan adalah keputusan untuk tidak mengadopsi suatu inovasi yang tersedia. Terdapat lima atribut dalam teori difusi inovasi yang menentukan tingkat adopsi inovasi, yaitu keuntungan relatif (relative advantage), kompatibilitas (compatibity), kompleksitas (complexity), trialibilitas (trialability) dan observabilitas (observability).

Data pada Tabel 3 menunjukkan bahwa atribut inovasi SNI mainan anak dilihat dari tingkat keuntungan relatifhingga saat ini belum terlihat jelas dapatmenaikan omzet penjualan, karena penerapannya belum lama dan belum seluruh pengrajin menerapkannya. Selain itu juga karena dari segi peningkatan mutu produk, pengrajin merasa mutu produk mereka memang sudah baik sejak sebelum menerapkan SNI mainan anak sehingga dampak penerapan SNI pada produk 
Tabel 3. Rentang Skor Atribut Inovasi SNI Mainan Anak

\begin{tabular}{lllcrc}
\hline No & Atribut inovasi SNI mainan anak $\left(\mathbf{X}_{\mathbf{4}}\right)$ & Kategori & Rentang skor & Jumlah & \% \\
\hline \multirow{2}{*}{1} & \multirow{2}{*}{ Tingkat keuntungan relatif } & rendah & $10,0-12,0$ & 25 & 54,3 \\
& & sedang & $12,1-14,0$ & 13 & 28,3 \\
& \multirow{2}{*}{ Tingkat kompatibilitas } & tinggi & $14,1-16,0$ & 8 & 17,4 \\
& & rendah & $11,0-14,0$ & 10 & 21,7 \\
& & sedang & $14,1-17,0$ & 34 & 73,9 \\
\multirow{2}{*}{3} & Tingkat kompleksitas & tinggi & $17,1-20,0$ & 2 & 4,3 \\
& & rendah & $6,0-9,3$ & 5 & 10,9 \\
& & sedang & $9,4-12,7$ & 33 & 71,7 \\
4 & \multirow{2}{*}{ Tingkat observabilitas } & tinggi & $12,8-16,0$ & 8 & 17,4 \\
& & rendah & $10,0-12,0$ & 20 & 43,5 \\
& & sedang & $12,1-14,0$ & 22 & 47,8 \\
\hline
\end{tabular}

Keterangan: $n=46$

boneka ini tidak terlalu terasa dari segi peningkatan mutu produk. Kondisi ini terjadi karena belum adanya kesadaran bahwa untuk menentukan mutu produk diperlukan sebuah ukuran syarat mutu serta pengujian yang dapat membuktikan mutu produk dan menjadi tolak ukur untuk mempertahankan mutu produk. Jika hal ini sudah disadari maka seperti disebutkan oleh Werdiyati (2011) dalam strategi pemasaran dan pengembangan usaha perdagangan boneka didapatkan strategi prioritas, yaitu menjaga mutu dan memunculkan ciri khas produk untuk mengantisipasi persaingan usaha.

Keuntungan yang dirasakan baru sebatas perlindungan hukum karena SNI telah diberlakukan wajib oleh Kementerian Perindustrian atas dasar faktor keamanan dan keselamatan, sehingga ketika dipasarkan tidak ada risiko akan ditarik dari peredaran. Keuntungan dari segi perluasan pasar dan peningkatan penjualan tidak dirasakan langsung, namun dirasakan para pedagang retail lebih memilih produk boneka yang telah sesuai SNI untuk mereka jual agar aman saat ada pengawasan pasar.

Tingkat kompatibilitas SNI mainan anak tergolong sedang. SNI mainan anak dianggap sesuai dengan nilai-nilai dan budaya perusahaan sehingga sejalan dengan kebutuhan kelangsungan usaha dan proses produksi saat ini. SNI mainan anak juga dianggap sesuai dengan kebutuhan konsumen atas jaminan keselamatan dan kemanaan boneka yang digunakan oleh anak-anak mereka. Pada syarat mutu
SNI mainan anak diatur tentang bahan yang digunakan dan kekuatan jahitan yang menentukan tingkat migrasi zat warna ataupun kekuatan tarik pada penggunaan yang tidak biasa misalnya dimasukkan ke mulut atau pun ditarik dengan kuat.

Pada data di Tabel 3 ditunjukkan bahwa tingkat kompleksitas SNI mainan anak tergolong kategori sedang. Hal ini menunjukkan bahwa bagi pengrajin boneka pemenuhan persyaratan dari segi kekuatan jahitan, pemenuhan pemilihan bahan yang tidak mudah terbakar dan bebas dari zat kimia beracun dapat dipenuhi dengan baik. Bahan boneka yang digunakan menurut pengrajin didapatkan dari pemasok yang memang sudah memiliki bahan kain yang lolos uji, sehingga pengrajin tidak perlu khawatir pada saat menggunakannya sebagai bahan baku boneka.

Adapun tingkat observabilitas SNI mainan anak bagi pengrajin tergolong kategori sedang, hal ini menunjukkan bahwa produk boneka yang sesuai SNI mainan anak relatif dapat diketahui langsung perbedaan fisiknya, terutama dari sisi filling-nya, boneka yang sesuai SNI akan menggunakan dakron yang baru dan bersih, sedangkan boneka yang tidak sesuai SNI biasanya diisi dengan limbah kain maupun dakron sisa produksi yang bentuknya tidak teratur dan kotor. Demikian halnya dengan tanda SNI yang asli pada produk boneka dapat diidentifikasi dengan melihat pencantuman nomor SNI, kode lembaga sertifikasi produk (LSPro) dan nomor registrasi produk. Beberapa produk boneka ada yang mencantumkan tanda SNI 
tanpa kode LSPro, hal ini membuat tanda SNI tersebut tidak dapat dilacak sehingga tidak dapat dibuktikan bahwa produk tersebut sudah lolos pengujian sesuai syarat mutu SNI mainan anak.

\section{Kinerja Pengrajin Boneka}

Kinerja diartikan sebagai suatu hasil kerja yang dicapai seseorang dalam melaksanakan tugas-tugasnya yang berdasarkan atas kecakapan, pengalaman dan kesungguhan serta waktu (Hasibuan 2006). Sebagai perilaku, kinerja mencakup tindakan-tindakan dan perilaku yang relevan dengan tujuan organisasi. Bagi sebuah organisasi, menurut Barney (2002), kinerja perusahaan didefinisikan sebagai perbandingan nilai yang diciptakan organisasi dengan penggunakan aset dan nilai yang diharapkan diperoleh oleh pemilik.

Kinerja pengrajin boneka dalam penerapan SNI mainan anak sesuai dengan Peraturan Direktur Jenderal Basis Industri Manufaktur Nomor:02/BIM/ PER/1/2014, tentang Petunjuk Teknis Pelaksanaan Pemberlakuan dan Pengawasan Penerapan Standar Nasional Indonesia (SNI) Mainan Secara Wajib dapat dilihat dari pemenuhan persyaratan administrasi, pemenuhan persyaratan pengujian dan pemenuhan persyaratan penandaan.

Pemenuhan persyaratan administrasi tergolong kategori tinggi. Sebagian besar dari pengrajin boneka sudah memiliki Surat Izin Usaha Industri (IUI) atau Tanda Daftar Industri (TDI) karena sesuai dengan
Peraturan Menteri Perindustrian Nomor:41/M-IND/ PER/2008 tentang Ketentuan dan Tata Cara Pemberian Izin Usahan Industri, Izin Perluasan dan Tanda Daftar Industri, dijelaskan bahwa setiap pendirian perusahaan industri wajib memiliki Izin Usaha Industri (IUI), dan bagi industri kecil wajib memiliki Tanda Daftar Industri(TDI). Sebagian pengrajin juga sudah memiliki sertifikat merek dan telah mengajukan registrasi SPPT SNI yang dilengkapi surat pernyataan jaminan tidak mengedarkan produk saat pengujian.

Pemenuhan syarat pengujian tergolong kategori tinggi, pengrajin merasa sanggup menyediakan contoh produksi untuk bahan pengujian dalam sertifikasi SNI. Pengrajin di Kota Bekasi memiliki SPPT SNI ada yang untuk produknya sendiri dan ada juga yang mendaftarkan produknya bersama melalui koperasi, hal ini karena biayanya cukup tinggi, sedangkan insentif yang tersedia hanya $50 \%$ dari keseluruhan biaya. Kebijakan adanya kewajiban melakukan pengujian produk setiap enam bulan juga termasuk berat untuk IKM karena tingginya biaya sertifikasi dibandingkan dengan modal, biaya produksi dan omzet penjualan sehingga perlu dikaji ulang.

Pemenuhan persyaratan penandaan tergolong tinggi (Tabel 4). Tanda SNI dijahit pada bagian bawah boneka dalam bentuk label pita satin sehingga mudah dibaca dan tidak mudah hilang meskipun melalui proses pencucian berulang kali. Label tersebut dicetak sesuai ukuran yang dipersyaratkan, dengan menyantumkan nomor SNI mainan anak serta nomor lembaga sertifikasi produk dan nomor registrasi

Tabel 4. Rentang Skor Kinerja Pengrajin Boneka dalam Penerapan SNI Mainan Anak

\begin{tabular}{|c|c|c|c|c|c|}
\hline No & $\begin{array}{l}\text { Kinerja pengrajin boneka } \\
\text { di Kota Bekasi }(Y)\end{array}$ & Kategori & $\begin{array}{c}\text { Rentang } \\
\text { skor }\end{array}$ & Jumlah & $\%$ \\
\hline \multirow{3}{*}{1} & \multirow{3}{*}{ Tingkat pemenuhan persyaratan administrasi } & rendah & $1,0-1,9$ & 9 & 19,6 \\
\hline & & sedang & $2,0-2,4$ & 8 & 17,4 \\
\hline & & tinggi & $2,5-3,0$ & 29 & 63,0 \\
\hline \multirow{3}{*}{2} & \multirow{3}{*}{ Tingkat pemenuhan persyaratan pengujian } & rendah & $1,0-1,9$ & 5 & 10,9 \\
\hline & & sedang & $2,0-2,4$ & 10 & 21,7 \\
\hline & & tinggi & $2,5-3,0$ & 31 & 67,4 \\
\hline \multirow{3}{*}{3} & \multirow{3}{*}{ Tingkat pemenuhan persyaratan penandaan } & rendah & $1,0-1,6$ & 2 & 4,3 \\
\hline & & sedang & $1,7-2,4$ & 6 & 13,0 \\
\hline & & tinggi & $2,5-3,0$ & 38 & 82,6 \\
\hline \multirow{3}{*}{4} & \multirow{3}{*}{ Peningkatan omzet penjualan } & rendah & $1,0-1,9$ & 25 & 54,3 \\
\hline & & sedang & $2,0-2,9$ & 19 & 41,3 \\
\hline & & tinggi & 3,0 & 2 & 4,3 \\
\hline
\end{tabular}


produk di bawahnya. Meskipun begitu sebagian besar pengrajin mengaku belum melaporkan realisasi produknya dengan alasan tidak tahu atau tidak diminta untuk melaporkannya.Hal ini perlu menjadi perhatian karena pelaporan realisasi produk sangat penting untuk pengawasan produk di pasar.

Sementara itu data pada Tabel 4 menunjukkan peningkatan omzet penjualan masih tergolong kategori rendah, karena pengrajin yang mengalami peningkatan omzet hanya sedikit. Hal ini dirasakan karena daya beli masyarakat yang sedang menurun sementara harga produk mengalami kenaikan.

\section{Hubungan Karakteristik Pengrajin dengan Kinerja Pengrajin Boneka di Kota Bekasi dalam Penerapan SNI Mainan Anak}

Pendidikan formal berhubungan dengan kinerja pengrajin dalam penerapan SNI mainan anak hanya sebatas pada pemenuhan persyaratan administrasi, dan tidak berhubungaan nyata dengan pemenuhan persyaratan pengujian dan penandaan, maupun dengan peningkat omzet, karena meskipun berpendidikan tinggi namun tidak merasakan pentingnya syarat mutu pada SNI mainan anak, maka pengrajin tidak merasa perlu memenuhi persyaratan lainnya untuk menerapkan SNI. Hal ini berlawanan dengan hasil penelitian Vionita (2013) yang menyatakan tingkat pendidikan yang tinggi dari seorang pegawai akan mempengaruhi kemampuannya dalam mencapai kinerja secara optimal.

Lamanya menjalankan usaha berhubungan nyata dengan pemenuhan persyaratan administrasi, artinya pengrajin yang telah cukup lama menjalankan usaha mampu memenuhi izin usaha dan sertifikat merek. Meskipun begitu lamanya usaha belum tentu membuat pengrajin mampu memenuhi persyaratan pengujian dan penandaan, serta mencapai peningkat omzet. Hal tersebut tidak sejalan dengan penelitian Firdausa (2012) bahwa semakin lama usaha dijalankan dan semakin banyak jam kerja maka semakin besar jumlah pendapatan pedagang tersebut

Tingkat kemampuan memenuhi permintaan pasar berhubung dengan peningkatan omzet, artinya jika pengrajin mampu memproduksi boneka sesuai jumlah yang dibutuhkan pasar maka otomatis maka omzet juga akan meningkat. Meskipun demikian kemampuan memenuhi permintaan tidak berhubungan dengan kinerja pengrajin dalam memenuhi seluruh persyaratan penerapan SNI, karena orientasi pasarnya masih terbatas pada pasar dalam negeri yang lebih mempertimbangkan jumlah dan waktu pengerjaan. Berbeda jika pengrajin berorientasi pasar ke negaranegara lain yang mengutamakan persyaratan kemanan mainan anak, hal ini seperti dinyatakan pada hasil penelitian Felgueira (2012) bahwa orientasi pasar adalah unsur pemersatu upaya dan proyek individu dan departemen, yang mengarah ke kinerja yang lebih tinggi.

Hasilpenelitian mengungkapkan bahwajumlah investasi usaha berhubungan dengan pemenuhan persyaratan administrasi (Tabel 5), hal ini karena izin usaha dan sertifikat merek adalah syarat utama untuk melaksanakan produksi, sedangkan pemenuhan persyaratan pengujian dan penandaan adalah biaya ekstra yang tidak dipertimbangkan sebagai biaya produksi. Pengrajin merasa biaya untuk memenuhi persyaratan pengujian dan penandaan cukup besar,

Tabel 5. Nilai Koefisien Korelasi antara Karakteristik Pengrajin dengan Kinerja Pengrajin Boneka di Kota Bekasi dalam Penerapan SNI Mainan Anak

\begin{tabular}{lllccc}
\hline \multirow{2}{*}{ No. } & Karakteristik pengrajin & \multicolumn{4}{c}{ Kinerja } \\
\cline { 3 - 6 } & $\begin{array}{c}\text { Persyaratan } \\
\text { administrasi }\end{array}$ & $\begin{array}{c}\text { Persyaratan } \\
\text { pengujian }\end{array}$ & $\begin{array}{c}\text { Persyaratan } \\
\text { penandaan }\end{array}$ & $\begin{array}{c}\text { Peningkatan } \\
\text { Omzet }\end{array}$ \\
\hline 1 & Pendidikan formal & $0,315^{*}$ & $-0,035$ & $-0,237$ & $-0,079$ \\
2 & Lama menjalankan usaha & $0,493^{* *}$ & 0,278 & 0,134 & 0,091 \\
3 & Kemampuan memenuhi & $-0,189$ & $-0,189$ & $-0,013$ & $0,405^{* *}$ \\
& permintaan pasar & $0,439^{* *}$ & 0,255 & 0,117 & 0,139 \\
\hline
\end{tabular}

Berhubungan nyata pada $\alpha=0,05$

** Berhubungan sangat nyata pada $\alpha=0,01$ 
sehingga dibutuhkan tambahan modal usaha yang dapat menerapkannya. Hal ini sejalan dengan hasil penelitian Ekowati (2012) dan Khoirrini (2014) yang menyebutkan bahwa modal (fisik, intelektual dan finansial) maupun modal insani dan modal sosial berpengaruh positif terhadap kinerja perusahaan, serta berpengaruh langsung dan signifikan terhadap kinerja.

\section{Hubungan Motivasi Wirausaha Pengrajin dengan Kinerja Pengrajin Boneka di Kota Bekasi dalam Penerapan SNI Mainan Anak}

Motivasi wirausaha berdasarkan kebutuhan kekuasaan berhubungan nyata dengan pemenuhan persyaratan administrasi dan pengujian, dengan memenuhi persyaratan administrasi dan pengujian produknya dapat dipasarkan tanpa takut ditarik dari pasar karena tidak sesuai dengan syaratmutu SNI (Tabel 6). Hal ini membuat pengrajin dapat mempertahankan usahanya, menyediakan lapangan pekerjaan untuk orang-orang di sekitarnya dan memiliki kesempatan untuk menjadi acuan dalam produksi boneka dengan prosedur yang jelas dan lolos uji laboratorium. Hal ini sejalan dengan penelitian Ochtaviana (2012) yang menyimpulkan bahwa karakteristik kewirausahaan dan motivasi berpengaruh positif dan signifikan terhadap keberhasilan usaha, dengan motivasi sebagai faktor yang paling dominan pengaruhnya terhadap keberhasilan usaha.

Dua sub variabel motivasi wirausaha pengrajin yang lainnya, yaitu kebutuhan prestasi dan kebutuhan afiliasi tidak berhubungan nyata dengan kinerja pengrajin, artinya peningkatan keduanya tidak berarti akan menyebabkan kinerja pengrajin akan naik juga. Hal ini tidak sejalan dengan hasil penelitian Yunal (2013) bahwa motivasi berwirausaha memberikan pengaruh terhadap pertumbuhan usaha dan hasil penelitian Larasati (2014) yang menyebutkan bahwa motivasi kerja yang terdiri dari kebutuhan prestasi, kebutuhan afiliasi dan kebutuhan kekuasaan secara simultan dan parsial memiliki pengaruh positif dan signifikan terhadap kinerja.

Tingkat kebutuhan prestasi tidak berhubungan dengan kinerja pengrajin dalam penerapan SNI, artinya keinginan untuk meningkatkan keadaan ekonomi tidak serta mertamembuat seorang pengrajin untuk menerapkan SNI. Pengrajin juga merasa untuk menghasilkan produk yang bermutu tidak harus dengan menerapkan SNI, melainkan bisa dengan memilih distributor bahan baku yang dapat dipercaya dan tidak menggunakan limbah sebagai isi boneka, padahal untuk menjamin hal tersebut dibutuhkan parameter dan hasil uji tertentu. Hal ini belum disadari sehingga ketika seorang pengrajin menerapkan SNI tidak kemudian akan meningkatkan status sosialnya, berbeda dengan jika ia mengalami kenaikan omzet penjualan yang akan membuatnya menjadi salah seorang yang dipandang berhasil oleh pengrajin lain.

Sementara itu tingkat kebutuhan afilisasi tidak berhubungan dengan kinerja pengrajin, karena seorang pengrajin yang belum menerapkan SNI, produknya tetap diterima oleh lingkungannya dan dapat bekerjasama dengan orang lain dalam memasarkan produknya. Hal ini tidak sejalan dengan penelitian Frianto (2012) yang menyebutkan bahwa lingkungan kerja mempunyai pengaruh terhadap kinerja.

\section{Hubungan Faktor Eksternal Pengrajin dengan Kinerja Pengrajin Boneka di Kota Bekasi dalam Penerapan SNI Mainan Anak}

Tingkat ketersediaan informasi berhubungan nyata dengan peningkatan omzet penjualan, hal ini karena dengan informasi yang cukup mengenai SNI mainan anak dapat membuat pengrajin mampu meyakinkan pasar untuk lebih memilih produknya.

Tabel 6. Nilai Koefisien Korelasi antara Motivasi Wirausaha Pengrajin dengan Kinerja Pengrajin

\begin{tabular}{llcccc}
\hline & \multirow{2}{*}{ Motivasi wirausaha } & \multicolumn{4}{c}{ Kinerja } \\
\cline { 3 - 6 } & & $\begin{array}{c}\text { Persyaratan } \\
\text { administrasi }\end{array}$ & $\begin{array}{c}\text { Persyaratan } \\
\text { pengujian }\end{array}$ & $\begin{array}{c}\text { Persyaratan } \\
\text { penandaan }\end{array}$ & $\begin{array}{c}\text { Peningkatan } \\
\text { Omzet }\end{array}$ \\
\hline 1 & Kebutuhan prestasi & 0,129 & $-0,180$ & 0,068 & 0,084 \\
2 & Kebutuhan kekuasaan & $0,338^{*}$ & $0,364^{*}$ & 0,132 & 0,224 \\
3 & Kebutuhan afiliasi & 0,185 & $-0,156$ & 0,072 & 0,073 \\
\hline
\end{tabular}

* Berhubungan nyata pada $\alpha=0,05$

** Berhubungan sangat nyata pada $\alpha=0,01$ 
Tabel 8. Nilai Koefisien Korelasi antara Atribut Inovasi dengan Kinerja Pengrajin

\begin{tabular}{|c|c|c|c|c|c|}
\hline \multirow[b]{2}{*}{ No. } & \multirow[b]{2}{*}{ Atribut inovasi } & \multicolumn{4}{|c|}{ Kinerja } \\
\hline & & $\begin{array}{c}\text { Persyaratan } \\
\text { administrasi }\end{array}$ & $\begin{array}{c}\text { Persyaratan } \\
\text { pengujian }\end{array}$ & $\begin{array}{c}\text { Persyaratan } \\
\text { penandaan }\end{array}$ & $\begin{array}{c}\text { Peningkatan } \\
\text { Omzet }\end{array}$ \\
\hline 1 & $\begin{array}{l}\text { Tingkat keuntungan } \\
\text { relatif }\end{array}$ & 0,182 & 0,074 & $-0,010$ & 0,290 \\
\hline 2 & Tingkat kompatibilitas & $-0,080$ & 0,106 & $-0,095$ & 0,200 \\
\hline 3 & Tingkat kompleksitas & $-0,140$ & 0,058 & $-0,094$ & 0,022 \\
\hline 4 & Tingkat observabilitas & $-0,202$ & 0,214 & 0,044 & 0,025 \\
\hline
\end{tabular}

Berhubungan nyata pada $\alpha=0,05$

** Berhubungan sangat nyata pada $\alpha=0,01$

Data pada Tabel 7 menunjukkan bahwa tingkat pemberdayaan pengrajin boneka melalui pelatihan berhubungan nyata dengan kinerja pengrajin boneka dalam hal pemenuhan persyaratan adimistrasi dan peningkatan omzet penjualan. Pelatihan yang diikuti oleh pengrajin dirasakan berguna untuk meningkatkan kompetensi pengrajin dalam penerapan SNI mainan anak.

Insentif penerapan SNI tidak berhubungan nyata dengan kinerja pengrajin karena jumlahnya insentif hanya sedikit sehingga tidak semua pengrajin mendapatkanya dan bagi pengrajin yang mendapatkannya, hanya disediakan $50 \%$ dari jumlah biaya sertifikasi yang dibutuhkan.

Tingkat pendampingan penerapan SNI mainan anak tidak berhubungan nyata dengan kinerja pengrajin, pendampingan ini dinilai kurang berhasil karena terbatasnya jumlah penyuluh membuat intensitas pertemuan menjadi sedikit, rata-rata pengrajin bertemu penyuluh hanya satu kali per tahun bahkan ada yang tidak pernah, padahal seperti disebutkan dalam penelitian Sumantri (2013) pendampingan yang berkelanjutan oleh ahli akan sangat membantu wirausaha untuk meningkatkan kinerja usaha.

\section{Hubungan Atribut Inovasi SNI Mainan Anak dengan Kinerja Pengrajin Boneka di Kota Bekasi dalam Penerapan SNI Mainan Anak}

Atribut inovasi SNI mainan anak secara keseluruhan tidak berhubungan nyata dengan kinerja pengrajin dalam penerapan SNI. Hal ini karena tingkat keuntungan relatif seperti peningkatan mutu dirasakan tidak terlalu penting karena pengrajin merasa bahwa selama ini produksi sudah mempertimbangan mutu.
Dari sisi penjualan juga dianggap tidak berpengaruh, ditambah kewajiban pengujian ulang setiap enam bulan sekali yang perlu tambahan biaya. Sedangkan dari segi perlindungan hukum, pengawasan masih kurang, sehingga pengrajin merasa meskipun tidak menerapkan SNI mereka masih tetap dapat memasarkan produknya dengan bebas.

Adapun dari tingkat kompatibilitas dan kompleksitas, pengrajin merasa bahwa tanpa menerapkan SNI, syarat mutu produk boneka sudah mereka penuhi dengan baik dari aspek kekuatan jahitan, pemilihan bahan yang tidak mudah terbakar maupun keamanan dari zat kimia berbahaya dan zat warna pada bahan boneka. Namun tentu saja hal ini adalah penilaian kasat mata yang tidak didukung hasil uji laboratorium. Penelitian ini juga menunjukkan bahwa tingkat observabilitas tidak menjadi pertimbangan pengrajin dalam penerapan SNI.

\section{Kesimpulan}

Kinerja pengrajin boneka dalam penerapan SNI mainan di Kota Bekasi tergolong tinggi. Hal ini menunjukkan adanya kesadaran pada diri pengrajin untuk menerapkan SNI mainan anak. Karakteristik pengrajin, motivasi wirausaha pengrajin dan faktor eksternal pengrajin masing-masing berhubungan dengan kinerja pengrajin, kecuali atribut inovasi, artinya keuntungan relatif, kompleksitas, kompatibilitas dan observabilitas SNI mainan anak tidak menjadi pertimbangan pengrajin boneka di Kota Bekasi dalam menerapkan SNI mainan anak. Secara keseluruhan, SNI mainan anak dapat diterapkan oleh pengrajin Boneka di Kota Bekasi namun hingga saat ini belum terlihat jelas dapat menaikan omzet penjualan, karena 
penerapannya belum lama dan belum seluruh pengrajin menerapkannya. Pedagang retail mulai lebih memilih produk boneka yang telah sesuai dengan SNI agar aman berjualan saat ada pengawasan pasar.

Saran terkait kebijakan atas kewajiban melakukan pengujian produk setiap enam bulan perlu dikaji ulang, karena tingginya biaya sertifikasi dibandingkan dengan modal, biaya produksi dan omzet penjualan termasuk berat untuk IKM. Pengawasan produk boneka bertanda SNI yang beredar di pasar juga harus ditingkatkan untuk mengapresiasi IKM yang telah mematuhi SNI wajib mainan anak dan disosialisasikan mekanisme pengawasannya agar tidak dapat disalahgunakan.

\section{Daftar Pustaka}

Barboza D, Story L. 2007. Mattel Issues New Recall of Toys Made in China [Internet]. [dapat diunduh dari:http://www.nytimes.com/2007/08/14/ business/15toys-web.html?pagewant ed=all]

Barney J. 2002. Gaining Sustaining Competitive Advantage. New York (US): Prentice Hall.

[BPOM] Badan Pengawas Obat dan Makanan. Sentra Informasi Keracunan Nasional. Bahaya Timbal pada Produk Mainan Anak-Anak. [Internet]. [dapat diunduh dari:http://ik.pom.go.id/v2014/ artikel/artikel-timbal_koran -terbit.pdf]

[BSN] Badan Standardisasi Nasional. 2011. SNI Penguat Daya Saing Bangsa (Satu Tahun Genap SNI 2010-2011). Jakarta (ID): BSN.

[CIA] Central Inteligence Agency. 2016. World Fact Book: Field Listing Age Structure. [Internet]. [dapat diunduh dari:https://www.cia.gov/library/ publications/the-world-factbook/geos/print/ country/countrypdf_id.pdf]

Ekowati S, Rusmana O, Mafudi. 2013. Pengaruh Modal Fisik, Modal Finansial, dan Modal Intelektual terhadap Kinerja Perusahaan pada Perusahaan Manufaktur di Bursa Efek Indonesia. Jurnal Online Onsoed: 1-23.[Internet]. [dapat diunduh dari:http://jos.unsoed.ac.id/index.php/ aom/ article/download/324/162]

Felgueira T, Rodrigues RG. 2012. Entrepreneurial Orientation, Market Orientation and Performance of Teachers and Researchers in Public Higher Education Institution. Public Policy and Administration Journal11 (4):703-718.

Firdausa RA. 2012. Pengaruh Modal Awal, Lama
Usaha dan Jam Kerja Terhadap Pendapatan Pedagang Kios di Pasar Bintoro Demak. [skripsi]. Semarang (ID): Universitas Diponegoro

Frianto A, Dewi SK. 2013. Pengaruh Lingkungan Kerja terhadap Kinerja Karyawan Melalui Motivasi. Jurnal Ilmiah Manajemen. 1 (4):1055-1065.

Hasibuan MSP. 2006.Manajemen Sumber Daya Manusia. Jakarta(ID): PT Haji Masagung.

[Kemenperin] Kementerian Perindustrian Republik Indonesia. 2013. Peraturan Menteri Perindustrian No.24/M-Ind/PER/4/2013. Tentang Pemberlakuan Standar Nassional Indonesia (SNI) Mainan Secara Wajib. Jakarta (ID): Kemenperin.

[Kemenperin] Kementerian Perindustrian Republik Indonesia. 2015. Peraturan Direktur Jenderal Basis Industri Manufaktur (BIM) Nomor. 02/BIM/ PER/1/2014 tentang Petunjuk Teknis Pelaksanaan Pemberlakuan dan Pengawasan SNI Mainan Secara Wajib. Jakarta(ID): Kemenperin.

Khoirrini L, Kartika L. 2014. Pengaruh Modal Insani dan Modal Sosial terhadap Kinerja (Studi Kasus Usaha Kecil dan Menengah (UKM) Makanan dan Minuman Kota Bogor). Jurnal Manajemen dan Organisasi 5 (3):245-258.

Larasati S, Gilang A. 2014. Pengaruh Motivasi Kerja terhadap Kinerja Karyawan Wilayah Telkom Jabar Barat Utara (Witel Bekasi). Jurnal Manajemen dan Organisasi 5 (3):200-213.

Mardikanto T. 2015. Pemberdayaan Masyarakat dalam Perspektif Kebijakan Publik. Bandung (ID): Penerbit Alfabeta.

Nadarajan RD. 2013. Not a Game: Recall Tragedy Drives International Efforts For Safer Toys. ISO Focus Maagazine 4(5/6): 14-17.

Ochtaviana D. 2012. Pengaruh Karakteristik Kewirausahaan dan Motivasi terhadap Keberhasilan Usaha pada Sentra UKM Boneka Kain di Sukamulya Bandung. [skripsi]. Bandung (ID): Universitas Komputer Indonesia.

Ocktilia H. 2004. Pemberdayaan Ekonomi Rakyat Melalui Penguatan Kemitraan Lokal (Kasus pada pengrajin boneka kain di kelurahan Sukagalih Kecamatan Sukajadi Kota Bandung). [tesis]. Bogor (ID): Institut Pertanian Bogor.

Rogers EM. 2003. Diffusion of Innovation. Edisi 5. New york(US): The Free Press.

Sumantri B, Fariyanti A, Winandi R. 2013. Faktor-faktor yang Berpengaruh terhadap Kinerja Usaha Wirausaha Wanita: Suatu Studi pada Industri Pangan Rumahan di Bogor. Jurnal Manajemen Teknologi 12 (3):252-277. 
SuryowatiE. 2013.95\% Mainan AnakDiimpor dariChina. [Internet]. [dapat diunduh dari: http://bisniskeuangan. kompas.com]

Story L, Barboza D. 2007. Mattel Recalls 19 Million Toys Sent From China. [Internet]. [dapat diunduh dar:http://www.nytimes.com/2007/08/15/ business/ worldbusiness/15imports.html?pagewanted=all. New York (US): nytimes.com

Vionita VG. 2013. Pengaruh Tingkat Pendidikan dan Motivasi Kerja Terhadap Kinerja Pegawai Tata Usaha SMK Negeri di Kota Payakumbuh. [skripsi]. Padang (ID): Universitas Negeri Padang. Werdiyati P. 2011. Strategi Pemasaran Dan Pengembangan Usaha Perdagangan Boneka CV. Hayashi Toys Rawa Lumbu Bekasi. [tesis]. Bogor (ID): Institut Pertanian Bogor.

Yunal VO. 2013. Analisa Pengaruh Motivasi Berwirausaha dan Inovasi Produk terhadap Pertumbuhan Usaha Kerajinan Gerabah di Lombok Barat. Jurnal AGORA: 1 (1):1-11. [Internet]. [dapat diunduh dari: http://studentjournal.petra.ac.id/index. php/manajemen-bisnis/article/view/25 0/191] 